\title{
Rapid Identification of Resistance Loci Effective Against Puccinia graminis f. sp. tritici Race TTKSK in 33 Spring Wheat Landraces
}

E. M. Babiker, T. C. Gordon, and J. M. Bonman, United States Department of Agriculture-Agricultural Research Service (USDA-ARS), Small Grains and Potato Germplasm Research Unit, Aberdeen, ID 83210; S. Chao, USDA-ARS, Cereal Crops Research, Fargo, ND 58102; M. N. Rouse, USDA-ARS, Cereal Disease Laboratory, St. Paul, MN 55108; G. Brown-Guedira, USDA-ARS, Plant Science Research Unit, Raleigh, NC 27606; S. Williamson, Department of Crop Science, North Carolina State University, Raleigh 27695; and Z. A. Pretorius, Department of Plant Sciences, University of the Free State, Bloemfontein 9300, South Africa

\begin{abstract}
Babiker, E. M., Gordon, T. C., Bonman, J. M., Chao, S., Rouse, M. N., Brown-Guedira, G., Williamson, S., and Pretorius, Z. A. 2016. Rapid identification of resistance loci effective against Puccinia graminis f. sp. tritici race TTKSK in 33 spring wheat landraces. Plant Dis. 100:331-336.

Wheat breeders worldwide are seeking new sources of resistance to Puccinia graminis f. sp. tritici race TTKSK. To prioritize field-resistant landraces for follow-up genetic studies to test for the presence of new resistance genes, seedling response to $P$. graminis f. sp. tritici race TTKSK, molecular markers linked to specific $S r$ genes, segregation ratios among progeny from crosses, and bulked segregant analyses (BSA) were used. In total, 33 spring wheat landraces with seedling resistance to $P$. graminis f. sp. tritici race TTKSK were crossed to a susceptible genotype, LMPG-6. The segregation ratios of stem rust reactions in $\mathrm{F}_{2}$ seedlings fit a single dominant gene model in 31 populations and progeny from two crosses

gave ambiguous results. Using the $90 \mathrm{~K}$ wheat single-nucleotide polymorphism genotyping platform, BSA showed that the seedling resistance in 29 accessions is probably controlled by loci on chromosome $2 \mathrm{BL}$. For the three remaining accessions, BSA revealed that the seedling resistance is most likely controlled by previously unreported genes. For confirmation, two populations were advanced to the $\mathrm{F}_{2: 3}$ and screened against $P$. graminis f. sp. tritici race TTKSK. Segregation of the $\mathrm{F}_{2: 3}$ families fit a 1:2:1 ratio for a single dominant gene. Using the $F_{2: 3}$ families, BSA located the TTKSK locus on chromosome 6DS to the same location as $\operatorname{Sr} 42$.
\end{abstract}

Wheat stem rust caused by the fungus Puccinia graminis f. sp. tritici Erikss. \& Henning is potentially the most devastating disease of wheat worldwide (Roelfs et al. 1992; Singh et al. 2011). Since 1956, stem rust has been controlled in North America through eradication of barberry (Berberis vulgaris), the pathogen's alternate host, and deployment of effective $\mathrm{Sr}$ genes in widely grown cultivars (Jin and Singh 2006; Kolmer et al. 2007). In the past decade, stem rust has reemerged as a threat to global wheat production with the evolution of new pathotypes, known as the $\mathrm{Ug} 99$ race group, that overcome the widely used stem rust resistance genes $\mathrm{Sr} 31, \mathrm{Sr} 24$, and $\mathrm{Sr} 36$ (Pretorius et al. 2000; Jin et al. 2008, 2009). The first occurrence of Ug99 was race TTKSK, collected in Uganda in 1998. P. graminis f. sp. tritici race TTKSK is significant due to its virulence on $\mathrm{Sr} 31$, which is widely deployed in spring wheat cultivars in developing countries (Singh et al. 2008). Race TTKSK evolved and gained additional virulence to $\mathrm{Sr} 24$ and $\mathrm{Sr} 36$, which are common stem rust resistance genes in U.S. hard and soft winter wheat, respectively (Jin et al. 2008, 2009). Another variant of TTKSK with virulence to lines with resistance gene $\mathrm{Sr} 9 \mathrm{~h}$ and designated as race TTKSF+ was detected in South Africa (Pretorius et al. 2012; Rouse et al. 2014). Currently, there are only five designated genes $(\mathrm{Sr} 9 \mathrm{~h}, \mathrm{Sr} 28, \mathrm{Sr} 42, \mathrm{Sr} 57$, and $\operatorname{SrTmp}$ ) originating from Triticum aestivum that are effective against $P$. graminis f. sp. tritici race TTKSK (Ghazvini et al. 2012; McVey and Hamilton 1985; Rouse et al. 2012). Recently, race TKTTF with virulence to a line with resistance gene $\operatorname{SrTmp}$ has been detected in Ethiopia (Olivera et al. 2015).

Due to the ongoing evolution of new $P$. graminis f. sp. tritici races and widespread susceptibility in wheat to the Ug99 race group, work is underway to identify new sources of $\mathrm{Ug} 99$ resistance. Wheat

Corresponding author: M. Bonman, E-mail: Mike.Bonman@ars.usda.gov

Accepted for publication 29 June 2015.

http://dx.doi.org/10.1094/PDIS-04-15-0466-RE

This article is in the public domain and not copyrightable. It may be freely reprinted with customary crediting of the source. The American Phytopathological Society, 2016. landraces represent a valuable gene pool for new sources of resistance to wheat pathogens. To discover potentially new resistance to Ug99, 2,509 spring wheat landraces from the United States Department of Agriculture-Agricultural Research Service (USDAARS) National Small Grains Collection were screened in Kenya, where $P$. graminis f. sp. tritici races TTKST and TTKSK are naturally present, and 246 showed field resistance as adult plants (Newcomb et al. 2013). However, it is not known which of these resistant landraces might have new TTKSK resistance genes. Developing an efficient means to identify the landraces most likely to carry new resistance genes would enable researchers to prioritize the materials for further genetic studies.

Bulked segregant analysis (BSA) has been used extensively to identify molecular markers associated with resistance genes and to assign resistance genes to a chromosomal location (Chantret et al. 2000; Michelmore et al. 1991; Shen et al. 2003). As an alternative to biparental mapping, BSA is both faster and less expensive and, thus, can be used to economically screen many populations. Singlenucleotide polymorphism (SNP) markers for wheat are now available and frequently used in genetic analysis. Compared with other molecular markers, SNP markers are cost effective, provide better genome coverage, and are amenable for genotyping using high-throughput automated scoring platforms (Wang et al. 2014). The purpose of the present study was to (i) characterize the inheritance of resistance to $P$. graminis f. sp. tritici race TTKSK in 33 wheat landraces and (ii) determine the likely chromosomal locations of the resistance genes. The results of this study will be used to select the most promising populations for further characterization and mapping as part of our goal of identifying new resistance genes.

\section{Materials and Methods}

Plant materials. Of the 246 resistant accessions previously identified, 78 were classified as having a higher level of field-resistance to Ug99 based on median infection responses (Newcomb et al. 2013). Of these, 25 originating from Ethiopia were excluded from the present study because these are likely not landraces (Tesfaye et al. 1991). The remaining 53 accessions were screened for the presence of $\mathrm{Sr} 22$ (Periyannan et al. 2011), Sr24 (Mago et al. 2005; Olson et al. 
2010), Sr26 (Liu et al. 2010), Sr31 (Saal and Wricke 1999), and Lr19/Sr25 (Prins et al. 2001) using linked molecular markers. Five accessions were removed from consideration because of the presence of $L r 19 / S r 25$. In addition, seven accessions were excluded due to seedling-stage susceptibility to $P$. graminis $\mathrm{f}$. sp. tritici race TTKSK. The remaining 41 accessions with seedling resistance to race TTKSK were crossed to the susceptible line LMPG-6 (Knott 1990), from which $F_{1}$ seed were obtained from 33 crosses. A single $F_{1}$ seed from each cross was sown to generate $F_{2}$ populations. To confirm the $F_{2}$ results from two populations, LMPG-6/PI 184221 and LMPG-6/PI 625696 were advanced to generate $\mathrm{F}_{2: 3}$ populations.

Seedling evaluations. Parents and the $33 \mathrm{~F}_{2}$ populations were screened with $P$. graminis $\mathrm{f}$. sp. tritici race TTKSK (isolate 04KEN156/04) at the USDA-ARS Cereal Disease Laboratory in St. Paul, MN following the protocol described by Rouse et al. (2011a). About 100 seedlings from each $F_{2}$ population were tested, and seedling infection types (IT) using the 0 -to- 4 scale developed by Stakman et al. (1962) were recorded. A $\chi^{2}$ analyses was performed to test for goodness-of-fit to the models of one, two, or four genes. To postulate the presence of one of the known $\mathrm{Sr}$ genes, the 33 resistant landraces were also tested against the $P$. graminis $\mathrm{f}$. sp. tritici races TRTTF (isolate 06YEM34-1), TTTTF (isolate 01MN84A-1-2), RKQQC (isolate 99KS76A), MCCFC (isolate 59KS19), TPMKC (isolate 74MN1409), QFCSC (isolate 06ND76C), QTHJC (isolate 75ND717C), RCRSC (isolate 77ND82A), SCCSC (isolate 09ID73-2), and QCCSM (isolate 75WA165-2A). Based on the initial BSA results, it was necessary to distinguish the gene on chromosome $2 \mathrm{BL}$ from $\mathrm{Sr} 9 \mathrm{~h}$. Therefore, nine of the landraces were screened against $P$. graminis $\mathrm{f}$. sp. tritici race TTKSF+ (isolate UVPgt61/1) at the University of Free State, South Africa (Pretorius et al. 2012). Race TTKSF+ is known to be virulent against $\mathrm{Sr} 9 \mathrm{~h}$ (Rouse et al. 2014). Two wheat cultivars with $\mathrm{Sr} 9 \mathrm{~h}$, 'Webster' and 'Matlabas', and line-37 were included as checks. Based on the BSA results, PI 184221, PI 625696, and PI 625661 were screened against $P$. graminis $\mathrm{f}$. sp. tritici race TKTTF (isolate 13ETH18-1) to distinguish the resistance in these landraces from SrTmp.

Genetics of seedling resistance to $P$. graminis $\mathrm{f}$. sp. tritici race TTKSK. To confirm the $\mathrm{F}_{2}$ results, 110 and $106 \mathrm{~F}_{2: 3}$ families were derived from LMPG-6/PI 184221 and LMPG-6/PI 625696, respectively. From each family, 15 to 20 seedlings were screened against $P$. graminis f. sp. tritici race TTKSK. Based on the IT, families were classified as homozygous resistant (HR), homozygous susceptible (HS), or segregating for resistance (Seg). A $\chi^{2}$ analysis was performed to test for goodness-of-fit to the expected ratio of 1:2:1 for a single resistance gene.

BSA. For each of the 33 populations, DNA was extracted from parents, $F_{1}$ seedlings, and two susceptible bulks comprising $10 F_{2}$ susceptible seedlings each. To confirm the $\mathrm{F}_{2}$ results for the PI 184221 and PI 625696 populations, DNA was extracted from parents and three susceptible and three resistant bulks, each comprising 5 to 10 $\mathrm{F}_{2: 3}$ families. Total genomic DNA was extracted from 4-week-old seedlings using the protocol previously described by Babiker et al. (2015). DNA samples were genotyped with the wheat 90K iSelect SNP genotyping platform following the manufacturer's protocol (Illumina Inc., San Diego, CA) at the USDA-ARS Cereal Crops Research Unit in Fargo, ND. Allele calling for each SNP was performed using Illumina's GenomeStudio v2011.1 and manually inspected for call accuracy. SNP markers were assigned to chromosomes and positioned according to the rescaled hexaploid wheat $90 \mathrm{~K}$ SNP consensus map (Wang et al. 2014).

Based on the BSA results, it was necessary to distinguish genes in PI 625696 and PI 184221 from Sr42 and SrTmp. Therefore, these two accessions were screened with simple-sequence repeat (SSR) markers $c f d 49, g p w 5182$, and barc183 to determine the presence of $S r 42$ (Hiebert et al. 2011). Markers $c f d 49$ and barc183 were previously found to be flanking a gene postulated to be SrTmp in two wheat genotypes, 'Ripper' and 'Blouk' (Lopez-Vera et al. 2014).

\section{Results}

Inheritance of seedling resistance to $P$. graminis f. $\mathbf{s p .}$ tritici race TTKSK. Of the 33 selected resistant accessions, 30 accessions exhibited IT of 2 and $2+$ when inoculated with $P$. graminis $\mathrm{f}$. sp. tritici race TTKSK versus IT of $3+$ to 4 for LMPG- 6 . Of the 33 selected landraces, 29 showed resistance to race RKQQC (Table 1). All of the 33 accessions were susceptible to $P$. graminis f. sp. tritici races TRTTF and TPMKC. Except for wheat landrace PI 626409, race TTTTF produced high IT on all tested accessions. When inoculated with $P$. graminis f. sp. tritici race TTKSK, wheat landraces PI 184221 and PI 626308 exhibited IT scores of 2-, the lowest observed for this race among the test materials. The $\mathrm{F}_{2}$ populations segregated for resistance to $P$. graminis $\mathrm{f}$. $\mathrm{sp}$. tritici race TTKSK with resistant seedlings exhibiting 2 and $2+$ IT and susceptible seedlings exhibiting IT of $3+$ and 4 . The responses of the $\mathrm{F}_{1}$ seedlings from all the crosses were resistant, with IT of $2-, 2$, and $2+$, which were similar to the reactions of the resistant parents, indicating dominant gene action. The $\mathrm{F}_{2}$ seedlings from 31 populations fit a $3: 1$ resistant/susceptible segregation ratio, indicating the presence of single dominant genes in each population (Table 2). One accession, PI 192187, exhibited an IT of ;13, and $\mathrm{F}_{1}$ seedlings from the LMPG-6/PI 192187 cross were resistant, with an IT score similar to the resistant parent. However, many $\mathrm{F}_{2}$ seedlings from this population displayed intermediate reactions to TTKSK, which made it difficult to classify most of the progeny as clearly resistant or susceptible; therefore, no markers linked to resistance were obtained from the BSA for this cross.

BSA and parents genotyping. For each of the remaining 32 crosses, BSA identified from 8 to 81 SNP markers as polymorphic both between the parents and between the resistant parent and susceptible bulks. BSA showed that the seedling resistance to race TTKSK in 29 accessions is likely controlled by loci on chromosome 2BL (Table 3). The chromosomal location and the IT of 2 displayed by these 29 accessions suggested that the race TTKSK resistance in these landraces could be due to $S r 9 h$. To verify these results, nine of these accessions were tested against $P$. graminis $\mathrm{f}$. $\mathrm{sp}$. tritici races TTKSF+ and TTKSF, which are known to be virulent and avirulent, respectively, on $\mathrm{Sr} 9 \mathrm{~h}$ (Rouse et al. 2014). The nine tested wheat landraces exhibited low IT of $1+, 2-$, and 2 when inoculated with $P$. graminis f. sp. tritici race TTKSF, which is avirulent on $\mathrm{Sr} 9 \mathrm{~h}$. Six of the accessions showed high IT of 3 and 4 when inoculated with $P$. graminis f. sp. tritici race TTKSF+, indicating the likely presence of $\mathrm{Sr} 9 \mathrm{~h}$ in these accessions. Three accessions displayed IT of $22+$ and $2++$ against TTKSF+ (Table 4$)$. The intermediate IT of $22+$ and $2+$ + compared with the low IT of $1+, 2-$, and 2 indicate that the three accessions may, indeed, possess $\mathrm{Sr} 9 \mathrm{~h}$. Further studies would be necessary to determine the genetics of the intermediate reactions in these three accessions.

The BSA from the three remaining populations indicated association with markers on chromosomes other than $2 \mathrm{~B}$. In LMPG-6/PI $625661 \mathrm{~F}_{2}$ population, $11 \mathrm{SNP}$ markers on chromosome 7AS and 4 on 1BL revealed polymorphism between parents as well as between PI 625661 and the susceptible bulks, suggesting that the TTKSK resistance could be controlled by an $\mathrm{Sr}$ gene on either $7 \mathrm{AS}$ or $1 \mathrm{BL}$ (Table 3). Due to a limited number of $\mathrm{F}_{2}$ seed for the LMPG-6/PI 625661 cross, we were not able to validate these results in an advanced population. In the LMPG-6/PI $625696 \mathrm{~F}_{2}$ population, evidence of association occurred on chromosomes 6AS, 6DS, and $3 \mathrm{AS}$. In the $\mathrm{F}_{2}$ population derived from LMPG-6/PI 184221, six SNP markers from chromosome $1 \mathrm{AS}$, five from $2 \mathrm{BL}$, one from $5 \mathrm{~B}$, and one from $6 \mathrm{DS}$ revealed polymorphism between parents as well as between PI 184221 and susceptible bulks (Table 3).

To confirm the BSA results from the $\mathrm{F}_{2}$ populations and identify markers cosegregating with resistance in populations that could have new $S r$ genes, two populations were advanced to $\mathrm{F}_{2: 3}$ and screened against $P$. graminis f. sp. tritici race TTKSK. Segregation of $\mathrm{F}_{2: 3}$ families from LMPG-6/PI 184221 and LMPG-6/PI 625696 crosses fit a 1:2:1 ratio for HR/Seg/HS $\left(\chi^{2}=0.78, P=0.67\right.$ and $\chi^{2}=0.39$, $P=0.14$, respectively), thus confirming the $\mathrm{F}_{2}$ results. In the LMPG-6/PI $184221 \mathrm{~F}_{2: 3}$ families, BSA identified one marker on $5 \mathrm{BL}$ and four on 6DS associated with resistance (Table 5). Only one of the markers detected in the $\mathrm{F}_{2}$ BSA on 6DS was also detected in the $\mathrm{F}_{2: 3}$ BSA. PI 184221 displayed an IT reaction similar to that of Sr42 and SrTmp to P. graminis f. sp. tritici race TTKSK (Jin and 
Singh 2006). Susceptibility of PI 184221 to $P$. graminis f. sp. tritici races TPMKC, MCCFC, TTTTF, TRTTF, and TKTTF and resistance to QCCSM, QTHJC, RCRSC, and TTKSK suggested the presence of either Sr42 or SrTmp in PI 184221 (Olivera et al. 2012a; Rouse and Jin 2011; Rouse et al. 2011b). To further test for the possible presence of $S r 42$ and $\operatorname{SrTmp}$, two SSR markers previously found to be associated with $S r 42$ and $\operatorname{SrTmp}$ were tested in PI 184221. SSR markers gpw5182 amplified a 158-bp fragment, while barc183 amplified 149- and 166-bp fragments from PI 184221, indicating that the TTKSK resistance in PI 184221 is likely due to $\mathrm{Sr} 42$. Using $\mathrm{F}_{2: 3}$ families from the LMPG-6/PI 625696 cross, BSA clearly identified 10 SNP markers located on the short arm of chromosome 6D associated with the TTKSK resistance (Table 5). Of the 10 SNPs detected, 2 were also found in the BSA of the $\mathrm{F}_{2}$ population. These markers localized in a region covering 10.4 centimorgans on chromosome 6DS. To test for possible redundancy with $\mathrm{Sr} 42$ or SrTmp, the two SSR markers linked to Sr42 were used to genotype PI 625696 (Ghazvini et al. 2012). SSR marker gpw5182 did not amplify a fragment from PI 625696 while barc 183 amplified 149- and 166-bp fragments. Consequently, we were unable to confirm that the TTKSK resistance in PI 625696 was due to the presence of $S r 42$ or SrTmp.

\section{Discussion}

As part of an effort to identify new genes for field resistance to the $\mathrm{Ug} 99$ race group of $P$. graminis f. sp. tritici, a diverse collection of 2,509 wheat landraces were evaluated in Kenya and 246 resistant accessions were identified (Newcomb et al. 2013). To select accessions for follow-up, we identified landraces with the lowest disease levels in the field and eliminated those unlikely to be true landraces. The assumption behind this approach is that landraces would be more likely to carry new resistance genes than would germplasm that had been previously used in wheat breeding. The process resulted in 41 selected accessions, from which 33 successful crosses were made. These 33 landraces were screened against an array of $P$. graminis f. sp. tritici races to postulate the presence of known resistance genes. $P$. graminis f. sp. tritici races TPMKC, TTTTF, and TRTTF were virulent on all of the tested landraces, except for PI 626409 in the case of the reaction to race TTTTF (resistant IT of 2+). $P$. graminis $\mathrm{f} . \mathrm{sp}$. tritici race TRTTF was detected in 2006 from stem rust samples from Yemen and Ethiopia (Olivera et al. 2012b). Race TTTTF was detected in the United States in 2000 and 2001 from stem rust collections from Texas and Minnesota, respectively (Jin 2005). Sr24 is effective against race TTTTF; however, results from tests with diagnostic markers for $\mathrm{Sr} 24$ showed that the TTTTF resistance in PI 626409 was not due to $S r 24$. The resistance to TTTTF in PI 626409 is likely due to an unknown gene, because Jin (2005) attributed the TTTTF resistance in most spring wheat cultivars to unknown $\mathrm{Sr}$ genes. The $\mathrm{F}_{1}$ seedlings from all crosses were resistant, with IT similar to the parents, indicating that the TTKSK resistance is characterized by dominant inheritance from each accession. The $F_{2}$ segregation ratios of 3:1 resistant/susceptible showed that seedling resistance to TTKSK in 31 accessions is controlled by single dominant genes. Crosses with PI 192187 and PI 623164 gave ambiguous segregation ratios. In LMPG-6/PI 192187, this ambiguity may be attributed to the reaction of the resistant parent, which exhibited an IT of ;13, with larger pustules toward the leaf base. This IT makes it difficult to classify each $\mathrm{F}_{2}$ seedling as either clearly resistant or susceptible. Therefore, this population will be advanced for analyses in fixed recombinant inbred lines.

Of the 33 tested landraces, 29 showed evidence of loci for resistance to race TTKSK on chromosome 2BL. Most of these landraces showed similar IT scores when tested against races TTKSK and

Table 1. Accession number, origin, and seedling infection types of wheat landraces tested against 11 physiologic races of Puccinia graminis f. sp. tritici ${ }^{\mathrm{a}}$

\begin{tabular}{|c|c|c|c|c|c|c|c|c|c|c|c|c|}
\hline Accession & Origin & TTKSK & MCCFC & QCCSM & QFCSC & QTHJC & SCCSC & RCRSC & RKQQC & TPMKC & TTTTF & TRTTF \\
\hline CItr 15035 & Afghanistan & 2 & $3+$ & ND & 4 & $3+$ & ND & $3+$ & $2-$ & 4 & $3+$ & 4 \\
\hline PI 165193 & Turkey & 2 & ;1 & $2+$ & 2 & 1 & $3-$ & $2-$ & $2-$ & 3 & 3 & 4 \\
\hline PI 165700 & Afghanistan & 2 & 4 & 4 & 4 & 4 & 4 & 4 & 2 & 4 & 4 & 4 \\
\hline PI 166675 & Turkey & 2 & 2 & $3+$ & $2+$ & $2+$ & $2+$ & 2 & 2 & $3-$ & 3 & 4 \\
\hline PI 167531 & Turkey & 2 & $3+$ & $3+$ & $2+$ & $3+$ & $3+$ & $3+$ & 2 & $3+$ & 4 & 4 \\
\hline PI 178188 & Turkey & 2 & 4 & 4 & $3+$ & $3-$ & 4 & $3-$ & 2 & 4 & 4 & 4 \\
\hline PI 181433 & Afghanistan & 2 & 4 & 4 & $3+$ & 4 & 4 & 4 & 2 & 3 & 4 & 4 \\
\hline PI 184221 & Serbia & $2-$ & $3+$ & $; 1$ & $2-$ & $2+$ & $3+$ & 3 & 4 & 4 & 4 & 4 \\
\hline PI 192187 & Portugal & $; 13$ & ; & $2+$ & 0 & $3-$ & 4 & $3+$ & 4 & 4 & 4 & 4 \\
\hline PI 220127 & Afghanistan & 2 & 4 & 4 & $3+$ & 4 & 4 & 4 & 2 & $3+$ & $3+$ & $3+$ \\
\hline PI 243779 & Iran & 2 & 4 & 4 & 3 & 4 & 4 & 4 & $; 1$ & 4 & 4 & 4 \\
\hline PI 24484 & Uzbekistan & 2 & $3+$ & 4 & 4 & $3+$ & 4 & 4 & 2 & 4 & 4 & 4 \\
\hline PI 347169 & Afghanistan & 2 & 4 & 4 & 4 & 4 & 4 & 4 & 2 & 4 & 4 & 4 \\
\hline PI 429407 & Iran & 2 & 4 & 3 & $3-$ & ND & $3+$ & $3-$ & $3-$ & 4 & 3 & 4 \\
\hline PI 623118 & Iran & $2+$ & 3 & ND & $3-$ & ND & $3+$ & ND & 2 & 4 & $3+$ & 4 \\
\hline PI 623162 & Iran & $2+$ & 4 & 4 & 4 & 4 & 4 & 4 & $2+$ & 4 & 4 & 4 \\
\hline PI 623164 & Iran & 2 & 4 & 4 & 4 & 4 & 4 & 4 & $3-$ & 4 & 4 & 4 \\
\hline PI 623355 & Iran & 2 & 4 & 4 & 4 & $3+$ & 4 & 3 & $2-$ & 4 & 4 & 4 \\
\hline PI 623582 & Iran & 2 & $3+$ & 4 & $3+$ & 4 & ND & 4 & $2+$ & $3+$ & 4 & 4 \\
\hline PI 623785 & Iran & 2 & 3 & 4 & 4 & $3+$ & $3+$ & $3-$ & 2 & $3+$ & $3-$ & $3+$ \\
\hline PI 624149 & Iran & $2+$ & 3 & 4 & $3+$ & $3+$ & $3+$ & $2+$ & $2-$ & 4 & 4 & 4 \\
\hline PI 625315 & Iran & $2+$ & 3 & ND & $2+$ & $2+$ & ND & 2 & $2-$ & 4 & 3 & 4 \\
\hline PI 625348 & Iran & $2+$ & $3+$ & ND & 2 & 2 & ND & 2 & 2 & 4 & 4 & 4 \\
\hline PI 625661 & Iran & $2+$ & 4 & 1 & 3 & 3 & $3+$ & 4 & 2 & 4 & 4 & 4 \\
\hline PI 625673 & Iran & 2 & 4 & ND & 3 & ND & ND & ND & 2 & 4 & 4 & 4 \\
\hline PI 625696 & Iran & 2 & $2+$ & 4 & $2+$ & $2+$ & 4 & $2+$ & $2+$ & $3+$ & 4 & 4 \\
\hline PI 626074 & Iran & 2 & 4 & 4 & 4 & 4 & 4 & 3 & 2 & 4 & 4 & 4 \\
\hline PI 626252 & Iran & 2 & 4 & $3-$ & 4 & 4 & 4 & 4 & 2 & 4 & $3-$ & 4 \\
\hline PI 626255 & Iran & 2 & 4 & 4 & $3+$ & 4 & 4 & 4 & $2-$ & 4 & $3+$ & 4 \\
\hline PI 626308 & Iran & $2-$ & $3-$ & 4 & 4 & ND & 4 & $3-$ & 2 & 4 & $3+$ & 4 \\
\hline PI 626409 & Iran & 2 & 3 & 4 & $3-$ & $3-$ & 0 & $2+$ & $2-$ & 4 & $2+$ & 4 \\
\hline PI 626491 & Iran & 2 & 4 & 4 & 4 & 4 & 4 & $3+$ & 2 & 4 & 4 & 4 \\
\hline PI 626634 & Iran & 2 & 4 & 4 & $3+$ & 4 & $3+$ & 3 & 2 & 4 & 4 & 4 \\
\hline
\end{tabular}

a $\mathrm{ND}=$ no data 
RKQQC, suggesting that the resistance in these landraces may be controlled by the same $\mathrm{Sr}$ gene. Five Ug99-effective $\mathrm{Sr}$ genes ( $\mathrm{Sr} 9 \mathrm{~h}, \mathrm{Sr} 28, \mathrm{Sr} 40, \mathrm{Sr} 39$, and $\mathrm{Sr} 47$ ) have been mapped to chromosome 2B. Sr39 and Sr47 are translocations from Aegilops speltoides (Klindworth et al. 2012; Niu et al. 2011) and $\mathrm{Sr} 40$ is a translocation from T. timopheevii (Dyck 1992); Sr39 and Sr40 are, both located on the short arm of chromosome 2B. Sr $9 h$ and $\mathrm{Sr} 28$ originated from $\mathrm{T}$. aestivum and are located on the long arm of chromosome 2B (Rouse et al. 2012, 2014). Many of the markers associated with the resistance in these 29 accessions mapped to chromosome 2BL. The $\mathrm{Sr} 9 \mathrm{~h}, \mathrm{Sr} 28$, $\mathrm{Sr} 39, \mathrm{Sr} 40$, and $\mathrm{Sr} 47$ monogenic lines displayed IT of $2, ; 13, ; 1,1$, and $2-$, respectively, to $P$. graminis $\mathrm{f}$. sp. tritici race TTKSK (Jin et al. 2007; Niu et al. 2011; Rouse et al. 2014). The IT associated with the various genes on chromosome $2 \mathrm{~B}$ versus race TTKSK are consistent with the presence of $S r 9 h$ in many of the accessions tested in this study. The presence of $\mathrm{Sr} 9 \mathrm{~h}$ in the landraces is further supported by the susceptibility of six of these landraces to $P$. graminis f. sp. tritici race TTKSF+, which is known to be virulent on $\mathrm{Sr} 9 h$ (Rouse et al. 2014). Further studies are needed, though, to verify the presence of $\mathrm{Sr} 9 \mathrm{~h}$ in the other three tested landraces with intermediate reaction to race TTKSK. BSA in the LMPG-6/PI $625661 \mathrm{~F}_{2}$ population revealed two regions on chromosome arms 7AS and 1BL associated with race TTKSK resistance. Chromosome arm 7AS is known to harbor $\mathrm{Sr} 44$, which confers resistance to $P$. graminis f. sp. tritici race TTKSK with an IT of $1+$ (Jin et al. 2007). Only Srl4 has been mapped to the long arm of chromosome 1B (McIntosh et al. 1995). The reaction of a monogenic line for $\mathrm{Sr} 14$ to $P$. graminis f. sp. tritici

Table 2. Segregation of resistance to Puccinia graminis f. sp. tritici race TTKSK in $\mathrm{F}_{2}$ progeny derived from 33 crosses between the susceptible wheat line LMPG-6 and resistant wheat landrace accessions

\begin{tabular}{|c|c|c|c|c|}
\hline \multirow[b]{2}{*}{ Population } & \multicolumn{2}{|c|}{ Number of individuals } & \multicolumn{2}{|c|}{ 3:1 ratio } \\
\hline & Resistant & $\overline{\text { Susceptible }}$ & $\chi^{2}$ & $P$ value ${ }^{\mathrm{a}}$ \\
\hline LMPG-6/CItr 15035 & 70 & 16 & 1.80 & 0.190 \\
\hline LMPG-6/PI 165193 & 49 & 18 & 0.12 & 0.720 \\
\hline LMPG-6/PI 165700 & 64 & 27 & 1.05 & 0.305 \\
\hline LMPG-6/PI 166675 & 43 & 15 & 0.02 & 0.879 \\
\hline LMPG-6/PI 167531 & 55 & 15 & 0.48 & 0.490 \\
\hline LMPG-6/PI 178188 & 68 & 22 & 0.02 & 0.900 \\
\hline LMPG-6/PI 181433 & 83 & 21 & 1.28 & 0.250 \\
\hline LMPG-6/PI 184221 & 64 & 26 & 0.73 & 0.394 \\
\hline LMPG-6/PI 192187 & 51 & 34 & 10.20 & 0.001 \\
\hline LMPG-6/PI 220127 & 71 & 20 & 0.44 & 0.507 \\
\hline LMPG-6/PI 243779 & 71 & 23 & 0.01 & 0.906 \\
\hline LMPG-6/PI 24484 & 85 & 20 & 1.98 & 0.159 \\
\hline LMPG-6/PI 347169 & 69 & 21 & 0.13 & 0.715 \\
\hline LMPG-6/PI 429407 & 82 & 17 & 3.20 & 0.070 \\
\hline LMPG-6/PI 623118 & 78 & 17 & 2.55 & 0.110 \\
\hline LMPG-6/PI 623162 & 73 & 24 & 0.01 & 0.950 \\
\hline LMPG-6/PI 623164 & 41 & 24 & 4.90 & 0.026 \\
\hline LMPG-6/PI 623355 & 81 & 30 & 0.24 & 0.624 \\
\hline LMPG-6/PI 623582 & 91 & 21 & 2.33 & 0.130 \\
\hline LMPG-6/PI 623785 & 89 & 20 & 2.57 & 0.110 \\
\hline LMPG-6/PI 624149 & 86 & 27 & 0.07 & 0.787 \\
\hline LMPG-6/PI 625315 & 67 & 20 & 0.19 & 0.665 \\
\hline LMPG-6/PI 625348 & 86 & 19 & 2.67 & 0.102 \\
\hline LMPG-6/PI 625661 & 96 & 22 & 2.54 & 0.110 \\
\hline LMPG-6/PI 625673 & 91 & 20 & 2.88 & 0.089 \\
\hline LMPG-6/PI 625696 & 81 & 21 & 1.06 & 0.303 \\
\hline LMPG-6/PI 626074 & 75 & 36 & 3.27 & 0.070 \\
\hline LMPG-6/PI 626252 & 74 & 19 & 1.03 & 0.310 \\
\hline LMPG-6/PI 626255 & 75 & 34 & 2.22 & 0.136 \\
\hline LMPG-6/PI 626308 & 80 & 33 & 1.06 & 0.303 \\
\hline LMPG-6/PI 626409 & 78 & 23 & 0.27 & 0.605 \\
\hline LMPG-6/PI 626491 & 95 & 27 & 0.53 & 0.460 \\
\hline LMPG-6/PI 626634 & 79 & 22 & 0.55 & 0.458 \\
\hline
\end{tabular}

race TTKSK was reported to be inconclusive (Jin et al. 2007). Because the IT of PI 625661 differs from that of both Sr44 and Sr14, and because $\mathrm{Sr} 44$ and $\mathrm{Sr} 14$ are derived from species related to T. aestivum, PI 625661 may carry a new $S r$ gene. This population is being advanced for further study. Two other populations showed potential for new resistance based on the $\mathrm{F}_{2} \mathrm{BSA}$ results. The BSA results from $\mathrm{F}_{2: 3}$ families from PI 625696 indicated that the resistance is most likely due to a dominant gene located on chromosome 6DS. The stem rust resistance gene $\mathrm{Sr} 42$ is the only TTKSK-resistant gene that has

Table 3. Chromosomal location of markers associated with resistance to Puccinia graminis f. sp. tritici race TTKSK as detected by bulk segregant analysis of $33 \mathrm{~F}_{2}$ populations

\begin{tabular}{|c|c|}
\hline Population & Chromosome locations of SNP markers ${ }^{a}$ \\
\hline LMPG-6/CItr 15035 & (24) $2 \mathrm{~B}$, , (3) $2 \mathrm{D}$, , (2) $2 \mathrm{~A}$, , (6) $3 \mathrm{AL}$ \\
\hline LMPG-6/PI 165193 & (25) $2 \mathrm{BL},(5) 4 \mathrm{~A}$, (3) 7B \\
\hline LMPG-6/PI 165700 & (9) $2 \mathrm{~B}$, (3) $2 \mathrm{AL}$ \\
\hline LMPG-6/PI 166675 & (34) $2 \mathrm{~B}$ \\
\hline LMPG-6/PI 167531 & (10) $2 \mathrm{BL}$, (2) $1 \mathrm{DS}$, (2) 7A \\
\hline LMPG-6/PI 178188 & (46) $2 \mathrm{~B},(9) 5 \mathrm{D}$, (4) $7 \mathrm{~A}$ \\
\hline LMPG-6/PI 181433 & (9) $2 \mathrm{BL},(3) 1 \mathrm{~B}$, (2) $6 \mathrm{~A}$ \\
\hline LMPG-6/PI 184221 & (6) $1 \mathrm{AS},(5) 2 \mathrm{BL}$, (1) 5BL, (1) $6 \mathrm{DS}$ \\
\hline LMPG-6/PI 192187 & (4) $2 \mathrm{~A}$, , (3) $6 \mathrm{~B}$, , (2) $7 \mathrm{~A}$, (2) $3 \mathrm{~B}$, (2) $1 \mathrm{~A}$ \\
\hline LMPG-6/PI 220127 & (47) $2 \mathrm{BL}$, (4) $2 \mathrm{D}$, (4) 7A \\
\hline LMPG-6/PI 243779 & (33) $2 \mathrm{~B}$, (4) 2D, (8) 4A \\
\hline LMPG-6/PI 24484 & (12) $2 \mathrm{BL}$ \\
\hline LMPG-6/PI 347169 & (25) $2 \mathrm{BL}$ \\
\hline LMPG-6/PI 429407 & (9) $2 \mathrm{BL}$, , (1) $2 \mathrm{~A}$ \\
\hline LMPG-6/PI 623118 & (28) $2 \mathrm{BL},(5) 4 \mathrm{~B},(5) 6 \mathrm{~B}$ \\
\hline LMPG-6/PI 623162 & (47) $2 \mathrm{~B},(7) 2 \mathrm{~A},(5) 7 \mathrm{~A}$ \\
\hline LMPG-6/PI 623164 & (33) $2 \mathrm{~B},(6) 6 \mathrm{~A}$, (3) $4 \mathrm{~A}$ \\
\hline LMPG-6/PI 623355 & (13) $2 \mathrm{BL},(2) 4 \mathrm{~A}$ \\
\hline LMPG-6/PI 623582 & (28) $2 \mathrm{BL},(5) 2 \mathrm{~A}$, (2) 6A, (2) 6B \\
\hline LMPG-6/PI 623785 & (19) $2 \mathrm{~B}$, (2) $5 \mathrm{~A}$, (2) $6 \mathrm{~B}$ \\
\hline LMPG-6/PI 624149 & (49) $2 \mathrm{~B},(32) 3 \mathrm{BS}$ \\
\hline LMPG-6/PI 625315 & (31) $2 \mathrm{BL},(9) 6 \mathrm{~A}$ \\
\hline LMPG-6/PI 625348 & (20) $2 \mathrm{BL},(2) 6 \mathrm{~B}$ \\
\hline LMPG-6/PI 625661 & (11) $7 \mathrm{AS}$, (4) $1 \mathrm{BL}$ \\
\hline LMPG-6/PI 625673 & (19) $2 \mathrm{BL}$ \\
\hline LMPG-6/PI 625696 & (9) $6 \mathrm{AS},(3) 6 \mathrm{DS}$, (3) $3 \mathrm{AS}$ \\
\hline LMPG-6/PI 626074 & (30) $2 \mathrm{~B}$, , (3) $6 \mathrm{~A}$ \\
\hline LMPG-6/PI 626252 & (7) $2 \mathrm{~B},(2) 2 \mathrm{~A}$ \\
\hline LMPG-6/PI 626255 & (31) $2 \mathrm{BL}$ \\
\hline LMPG-6/PI 626308 & (19) $2 \mathrm{BL},(7) 1 \mathrm{~B}$, (9) $3 \mathrm{AL}$, (4) $3 \mathrm{~B}$, (10) $6 \mathrm{~A}$ \\
\hline LMPG-6/PI 626409 & (18) $2 \mathrm{BL},(2) 6 \mathrm{~B},(2) 7 \mathrm{~B}$ \\
\hline LMPG-6/PI 626491 & (16) $2 \mathrm{BL},(5) 7 \mathrm{BL}$ \\
\hline LMPG-6/PI 626634 & (34) $2 \mathrm{~B},(2) 6 \mathrm{~B}$, , (2) 6D \\
\hline
\end{tabular}

Table 4. Reactions of spring wheat landraces tested against Puccinia graminis f. sp. tritici races TTKSF and TTKSF+ and $\mathrm{Sr}$ gene postulation

\begin{tabular}{lccc}
\hline Accession & TTKSF & TTKSF+ & Sr gene postulation \\
\hline PI 178188 & $1+$ & 4 & $\operatorname{Sr} 9 h$ \\
PI 623118 & $2-$ & 3 & Sr9h \\
PI 623582 & 2 & 4 & Sr9h \\
PI 623785 & 2 & 4 & Sr9h \\
PI 625315 & 2 & $2++$ & $\operatorname{Sr} 9 h+$ \\
PI 625348 & 2 & $2++$ & $\operatorname{Sr} 9 h+$ \\
PI 626255 & $2-$ & 4 & $\operatorname{Sr} 9 h$ \\
PI 626409 & 2 & $22+$ & $\operatorname{Sr} 9 h+$ \\
PI 626491 & 2 & 3 & $\operatorname{Sr} 9 h$ \\
Matlabas & $2-$ & 4 & $\operatorname{Sr} 9 h$ \\
Webster & 2 & 4 & $\operatorname{Sr} 9 h$ \\
Line 37 & 4 & 4 & no \\
\hline
\end{tabular}

a $\mathrm{Sr} 9 h+$ indicated the presence of $\mathrm{Sr} 9 h$ plus an additional $\mathrm{Sr}$ gene. 
been mapped to 6DS (Ghazvini et al. 2012). PI 625696 displayed an IT similar to that described for $\mathrm{Sr} 42$ when tested against $P$. graminis f. sp. tritici race TTKSK but, when tested against $P$. graminis $\mathrm{f}$. sp. tritici races QFCSC, QTHJC, and MCCFC, PI 625696 displayed an IT of $2+$, which differs from the IT of $33+$ described for Norin 40 ( $S r 42)$ in response to these races (Ghazvini et al. 2012). The resistance of PI 625696 to $P$. graminis f. sp. tritici races QFCSC, QTHJC, MCCFC, and RKQQC may be due to an additional $\mathrm{Sr}$ gene.

Although $\chi^{2}$ analysis revealed single dominant genes in 31 of the landraces, several markers from different chromosomes showed polymorphism between parents as well as between the resistant parent and susceptible bulks. These polymorphisms from multiple chromosomes could be attributed to the presence of paralogous loci as a consequence the hexaploid nature of common wheat (Wang et al. 2014). BSA in the $F_{2}$ population derived from LMPG-6/PI 184221 detected four potential locations for the TTKSK resistance. Using the $\mathrm{F}_{2: 3}$ families, BSA detected only two potential locations on chromosome 5BL and 6DS. Based on the susceptibility of PI 184221 to $P$. graminis f. sp. tritici races TPMKC, MCCFC, TTTTF, TKTTF, and TRTTF and resistance to QCCSM, QTHJC, RCRSC, and TTKSK, the TTKSK resistance in PI 184221 may be due to $S r 42, \operatorname{SrTmp}$, or a new gene. The stem rust resistance gene $\operatorname{SrTmp}$ originally was derived from the hard red winter wheat 'Triumph 64' (McVey and Hamilton 1985) and it has been postulated to be present in several wheat cultivars from Eastern Europe and in a small group of wheat cultivars from the United States (Jin and Singh 2006; McVey and Hamilton 1985). Recently, a gene for TTKSK resistance from two wheat cultivars, Blouk and Ripper, was mapped to chromosome 6DS at a similar location compared with that of $\mathrm{Sr} 42$ and postulated to be SrTmp (Lopez-Versa et al. 2014). Based on the IT, race specificity, and marker results, the TTKSK resistance in PI 184221 can be attributed to SrTmp or Sr42, similar to Blouk and Ripper. Because the TTKSK-resistant landraces were susceptible to TRTTF and several domestic races, resistance from these landraces should be combined with genes effective against TRTTF and domestic races. In addition, landrace accessions may contain deleterious traits compared with most modern wheat germplasm, and some degree of prebreeding via backcrossing to adapted germplasm may be necessary before the resistance genes from these accessions could be deployed in a breeding program. In this study, seedling response to $P$. graminis f. sp. tritici race TTKSK, molecular markers linked to specific $S r$ genes, population segregation ratios, and BSA results using genome-wide SNPs were used to identify three wheat landraces with higher priority

Table 5. Single-nucleotide polymorphism (SNP) markers associated with Puccinia graminis f. sp. tritici race TTKSK resistance in PI 625696 and PI 184221 as detected by bulked segregant analysis of $\mathrm{F}_{2: 3}$ families

\begin{tabular}{lccc}
\hline Accession, SNP ID $^{\mathbf{a}}$ & Chromosome & Arm & Distance (cM) \\
\hline PI 625696 & & & \\
IWB55116 & 6D & S & 14.347 \\
IWB20798 & 6D & S & 16.243 \\
IWB28838 & 6D & S & 18.996 \\
IWB262 & 6D & S & 21.827 \\
IWA984 & 6D & S & 22.925 \\
IWB61233 & 6D & S & 22.925 \\
IWB59282 & 6D & S & 22.925 \\
IWB47567 & 6D & S & 22.925 \\
IWB6902.2 & 6D & S & 23.841 \\
IWB48184 & 6D & S & 24.766 \\
PI 184221 & & & \\
IWB7108 & 6D &. & 9.471 \\
IWB10804 & 6D &. & 9.471 \\
IWB6072.2 & 6D & S & 23.841 \\
IWB11787 & 6D & S & 24.766 \\
IWB3275 & 5B & L & 143.548 \\
\hline
\end{tabular}

a Markers in bold also detected by bulk segregant analysis of the $\mathrm{F}_{2}$ population.

b Distance in centimorgans (cM) based on a reference consensus map (Wang et al. 2014). for follow-up studies. Resistance in PI 625696 and PI 184221 may be controlled by either $S r 42$ or SrTmp or a novel gene whereas, in PI 625661, the TTKSK resistance may be due to either $S r 14$ or a novel gene. Similar utilization of the $90 \mathrm{~K}$ iSelect SNP genotyping assay for BSA to rapidly prioritize germplasm may be applicable to studies of diverse traits in wheat.

\section{Acknowledgments}

We thank S. Stoxen and S. Gale for their technical assistance. This research was supported by the USDA-ARS National Plant Disease Recovery System, the USDA-ARS CRIS project 2050-21000-029-00D, and the Durable Rust Resistance in Wheat (DRRW) project managed by Cornell University and funded by the Bill and Melinda Gates Foundation and the United Kingdom Department for International development. This work was supported, in part, by National Research Initiative Competitive Grant 2011-68002-30029 (Triticeae-CAP) from the USDA National Institute of Food and Agriculture.

\section{Literature Cited}

Babiker, E. M., Gordon, T. C., Chao, S., Newcomb, M., Rouse, M. N., Jin, Y., Wanyera, R., Acevedo, M., Brown-Guedira, G., Williamson, S., and Bonman, J. M. 2015. Mapping resistance to the Ug99 race group of the stem rust pathogen in a spring wheat landrace. Theor. Appl. Genet. 128:605-612.

Chantret, N., Sourdille, P., Roder, M., Tavaud, M., Bernard, M., and Doussinault, G. 2000. Location and mapping of the powdery mildew resistance gene MlRE and detection of a resistance QTL by bulked segregant analysis (BSA) with microsatellites in wheat. Theor. Appl. Genet. 100:1217-1224.

Dyck, P. L. 1992. Transfer of a gene for stem rust resistance from Triticum araraticum to hexaploid wheat. Genome 35:788-792.

Ghazvini, H., Hiebert, C. W., Zegeye, T., Liu, S., Dilawari, M., Tsilo, T., Anderson, J. W., Rouse, M. N., Jin, Y., and Fetch, T. 2012. Inheritance of resistance to Ug99 stem rust in wheat cultivar Norin 40 and genetic mapping of Sr42. Theor. Appl. Genet. 125:817-824

Hiebert, C. W., Fetch, T. G., Jr., Zegeye, T., Thomas, J. B., Somers, D. J., Humphreys, D. G., McCallum, B. D., Cloutier, S., Singh, D., and Knott, D. R. 2011. Genetics and mapping of seedling resistance to Ug99 stem rust in Canadian wheat cultivars 'Peace' and 'AC Cadillac'. Theor. Appl. Genet. 122:143-149.

Jin, Y. 2005. Races of Puccinia graminis identified in the United States during 2003. Plant Dis. 89:1125-1127.

Jin, Y., and Singh, R. P. 2006. Resistance in U.S. wheat to recent eastern African isolates of Puccinia graminis f. sp. tritici with virulence to resistance gene $S r 31$. Plant Dis. 90:476-480.

Jin, Y., Singh, R. P., Ward, R. W., Wanyera, R., Kinyau, M., Njau, P., Fetch, T., Pretorius, Z. A., and Yahyaoui, A. 2007. Characterization of seedling infection types and adult plant infection responses of monogenic $S r$ gene lines to race TTKS of Puccinia graminis f. sp. tritici. Plant Dis. 91:1096-1099.

Jin, Y., Szabo, L., Rouse, M., Fetch, T., Pretorius, Z. A., Wanyera, R., and Njau, P. 2009. Detection of virulence to resistance gene $S r 36$ within race TTKS lineage of Puccinia graminis f. sp. tritici. Plant Dis. 93:367-370.

Jin, Y., Szabo, L. J., Pretorius, Z. A., Singh, R. P., Ward, R., and Fetch, T. 2008. Detection of virulence to resistance gene $\mathrm{Sr} 24$ within race TTKS of Puccinia graminis f. sp. tritici. Plant Dis. 92:923-926.

Klindworth, D. L., Niu, Z., Chao, S., Friesen, T., Jin, Y., Faris, J. D., Cai, X., and $\mathrm{Xu}, \mathrm{S}$. S. 2012. Introgression and characterization of a goatgrass gene for a high level of resistance to Ug99 stem rust in tetraploid wheat. G3 (Bethesda) 2: 665-673.

Knott, D. R. 1990. Near-isogenic lines of wheat carrying genes for stem rust resistance. Crop Sci. 30:901-905.

Kolmer, J. A., Jin, Y., and Long, D. L. 2007. Wheat leaf and stem rust in the United States. Aust. J. Agric. Res. 58:631-638.

Liu, S., Yu, L.-X., Singh, R. P., Yu, J., Sorrells, M. E., and Anderson, J. A. 2010. Diagnostic and co-dominant PCR markers for wheat stem rust resistance genes Sr25 and Sr26. Theor. Appl. Genet. 120:691-697.

Lopez-Vera, E. E., Nelson, S., Singh, R. P., Basnet, B. R., Haley, S. D., Bhavani, S., Huerta-Espino, J., Xoconostle-Cazares, B. G., Ruith-Medrano, R., Rouse, M. N., and Singh, S. 2014. Resistance to stem rust Ug99 in six bread wheat cultivars maps to chromosome 6DS. Theor. Appl. Genet. 127:231-239.

Mago, R., Bariana, H. S., Dundas, I. S., Spielmeyer, W., Lawrence, G. J., Pryor, A. J., and Ellis, J. G. 2005. Development of PCR markers for the selection of wheat stem rust resistance genes $\operatorname{Sr} 24$ and $S r 26$ in diverse wheat germplasm. Theor. Appl. Genet. 111:496-504.

McIntosh, R. A., Wellings, C. R., and Park, R. F. 1995. Wheat Rusts: An Atlas of Resistance Genes. CSIRO, East Melbourne, Australia.

McVey, D. V., and Hamilton, K. 1985. Stem rust resistance gene from Triumph 64 identified in four other winter wheats. Plant Dis. 69:217-218.

Michelmore, R. W., Paran, I., and Kesseli, R. V. 1991. Identification of markers linked to disease-resistance genes by bulked segregant analysis: A rapid method to detect markers in specific genomic regions by using segregating populations. Proc. Natl. Acad. Sci. USA 88:9828-9832.

Newcomb, M., Acevedo, M., Bockelman, H. E., Brown-Guedira, G., Jackson, E. W., Jin, Y., Njau, P., Rouse, M. N., Singh, D., Wanyera, R., Goates, B. J., 
and Bonman, J. M. 2013. Field resistance to the Ug99 race group of the stem rust pathogen in spring wheat landraces. Plant Dis. 97:882-890.

Niu, Z., Klindworth, D. L., Friesen, T. L., Chao, S., Jin, Y., Cai, X., and Xu, S. S. 2011. Targeted introgression of a wheat stem rust resistance gene by DNA marker-assisted chromosome engineering. Genetics 187:1011-1021.

Olivera, P., Newcomb, M., Szabo, L., Rouse, M. N., Johnson, J., Gale, S., Luster, D. G., Hodson, D., Cox, J. D., Burgin, L., Hort, M., Gilligan, C. A., Patpour, M., Justesen, A. F., Hovmollar, M. S., Woldeab, G., Hailu, E., Hundie, B., Tadesse, K., Pumphrey, M., Singh, R. P., and Jin, Y. 2015. Phenotypic and genotypic characterization of race TKTTF of Puccinia graminis $\mathrm{f}$. sp. tritici that caused a wheat stem rust epidemic in southern Ethiopia in 2013/14. Phytopathology 105:917-928.

Olivera, P. D., Badebo, A., Xu, S. S., Klindworth, D. L., and Jin, Y. 2012a. Resistance to Race TTKSK of Puccinia graminis f. sp. tritici in Emmer Wheat. Crop Sci. 52:2234-2242.

Olivera, P. D., Jin, Y., Rouse, M., Badebo, A., Fetch, T., Singh, R. P., and Yahyaoui, A. 2012b. Races of Puccinia graminis f. sp. tritici with combined virulence to $\mathrm{Srl3}$ and $\mathrm{Sr} 9 \mathrm{e}$ in a field stem rust screening nursery in Ethiopia. Plant Dis. 96:623-628.

Olson, E. L., Brown-Guedira, G., Marshall, D. S., Jin, Y., Mergoum, M., Lowe, I., and Dubcovsky, J. 2010. Genotyping of U.S. wheat germplasm for presence of stem rust resistance genes $S r 24, S r 36$, and $\operatorname{Sr} 1 R S^{\text {Amigo }}$. Crop Sci. 50:668-675.

Periyannan, S. K., Bansal, U. K., Bariana, H. S., Pumphrey, M., and Lagudah, E. S. 2011. A robust molecular marker for the detection of shortened introgressed segment carrying the stem rust resistance gene $\mathrm{Sr} 22$ in common wheat. Theor. Appl. Genet. 122:1-7.

Pretorius, Z. A., Singh, R. P., Wagoire, W. W., and Payne, T. S. 2000. Detection of virulence to wheat stem rust resistance gene $S r 31$ in Puccinia graminis $\mathrm{f}$. sp. tritici in Uganda. Plant Dis. 84:203.

Pretorius, Z. A., Szabo, L. J., Boshoff, W. H. P., Herselman, L., and Visser, B. 2012. First report of a new TTKSF race of wheat stem rust (Puccinia graminis f. sp. tritici) in South Africa and Zimbabwe. Plant Dis. 96:590.

Prins, R., Groenewald, J. Z., Marais, G. F., Snape, J. W., and Koebner, R. M. D 2001. AFLP and STS tagging of Lr19, a gene conferring resistance to leaf rust in wheat. Theor. Appl. Genet. 103:618-624.

Roelfs, A. P., Singh, R. P., and Saari, E. E. 1992. Diseases of Wheat: Concepts and Methods of Disease Management. CIMMYT, Mexico City, Mexico.

Rouse, M., and Jin, Y. 2011. Stem rust resistance in A-genome diploid relatives of wheat. Plant Dis. 95:941-944.
Rouse, M., Wanyera, R., Njau, P., and Jin, Y. 2011a. Sources of resistance to stem rust race Ug99 in spring wheat germplasm. Plant Dis. 95:762-766.

Rouse, M. N., Nava, I. C., Chao, S., Anderson, J. A., and Jin, Y. 2012. Identification of markers linked to the race $\mathrm{Ug} 99$ effective stem rust resistance gene $\mathrm{Sr} 28$ in wheat (Triticum aestivum L.). Theor. Appl. Genet. 125:877-885.

Rouse, M. N., Nirmala, Y., Jin, Y., Chao, S., Fetch, T. G., Jr., Pretorius, Z. A., and Hiebert, C. W. 2014. Characterization of $\mathrm{Sr} 9 \mathrm{~h}$, a wheat stem rust resistance allele effective to Ug99. Theor. Appl. Genet. 127:1681-1688.

Rouse, M. N., Olson, E. L., Gill, B. S., Pumphrey, M. O., and Jin, Y. 2011b. Stem rust resistance in Aegilops tauschii germplasm. Crop Sci. 51:20742078.

Saal, B., and Wricke, G. 1999. Development of simple sequence repeat markers in rye (Secale cereale L.). Genome 42:964-972.

Shen, X., Zhou, M., Lu, W., and Ohm, H. 2003. Detection of Fusarium head blight resistance QTL in a wheat population using bulked segregant analysis. Theor. Appl. Genet. 106:1041-1047.

Singh, R. P., Hodson, D. P., Huerta-Espino, J., Jin, Y., Bhavani, S., Njau, P. Herrera-Foessel, S. A., Singh, P. K., Singh, S., and Govindan, V. 2011. The emergence of Ug99 races of the stem rust fungus is a threat to world wheat production. Annu. Rev. Phytopathol. 49:465-481.

Singh, R. P., Hodson, D. P., Huerta-Espino, J., Jin, Y., Herrera-Foessel, S. A., Wanyera, R., Herrera-Foessel, S. A., and Ward, R. W. 2008. Will stem rust destroy the world's wheat crop? Adv. Agron. 98:271-309.

Stakman, E. C., Stewart, D. M., and Loegering, W. Q. 1962. Identification of physiologic races of Puccinia graminis var. tritici. U. S. Dep. Agric. Agric. Res. Serv. E-617, Washington, DC

Tesfaye, T., Getachew, B., and Orede, M. 1991. Morphological diversity in tetraploid wheat landrace populations from the central highlands of Ethiopia. Hereditas 114:171-176.

Wang, S. D., Wong, D., Forrest, K., Allen, A., Chao, S., Huang, E., Maccaferri, M., Salvi, S., Milner, S., Cattievelli, L., Mastrangelo, A. M., Whan, A., Stephen, S., Barker, G., Wieseke, R., Plieske, J., International Wheat Genome Sequencing Consortium, Lillemo, M., Mather, D., Apples, R., Dolferus, R., Brown-Guedira, G., Korol, A., Akhunova, A. R., Feuillet, C., Salse, J., Morgante, M., Pozniak, C., Ming-Cheng, L., Dvorak, J., Morell, M., Dubcovsky, J., Ganal, M., Tuberosa, R., Lawley, C., Mikoulitch, I., Cavanagh, C., Edwards, K. E., Hayden, M., and Akhunov, E. 2014. Characterization of polyploid wheat genomic diversity using a high-density 90000 single nucleotide polymorphism array. Plant Biotechnol. J. 12:787-796. 